[Agr. Biol. Chem., Vol. 36, No. 1, p. 76 83, 1972]

\title{
The Microbial Metabolism of Methanol
}

\author{
Part II. Properties of Crystalline Alcohol Oxidase \\ from Kloeckera sp. No. 2201
}

\author{
By Yoshiki Tani, Toyofumi MiYa and Koichi Ogata \\ Department of Agricultural Chemistry, Kyoto University, Kyoto \\ Received July 14, 1971
}

\begin{abstract}
With the crystalline preparation of alcohol oxidase of Kloeckera sp. No. 2201 grown on methanol as a sole carbon source, some properties of the enzyme were investigated. The visible absorption spectrum showed maxima at $373 \mathrm{~m} \mu, 392 \mathrm{~m} \mu$ and $461 \mathrm{~m} \mu$ which were bleached by an addition of substrate and were restored by oxygenation. The prosthetic group was identified to be FAD. The enzyme was unstable in acidic $\mathrm{pH}$ and higher temperature. The optima of $\mathrm{pH}$ and temperature for enzyme activity were $\mathrm{pH}$ 8.0 and $35^{\circ} \mathrm{C}$, respectively. The $K m$ values were $1.25 \times 10^{-3} \mathrm{M}$ for methanol and $2.5 \times$ $10^{-3} \mathrm{M}$ for ethanol. The enzyme oxidized lower primary alcohols to the corresponding aldehydes and hydrogen peroxide.
\end{abstract}

In the previous paper, ${ }^{11}$ the authors have reported that a methanol-oxidizing enzyme was inducibly formed in cells of a methanolutilizing yeast, Kloeckera sp. No. 2201, when they were grown on methanol as a sole carbon source. The fungal enzyme was purified from the cell-free extract of the yeast by a procedure involving ammonium sulfate fractionation, DEAE-cellulose and Sephadex G-200 column chromatographies and crystallization. The enzyme was characterized to be an oxidase, which differed from other methanoloxidizing enzymes in methanol-utilizing microorganisms.

In the present paper, the authors wish to report some properties of the oxidase of Kloeckera sp. No. 2201.

\section{MATERIALS AND METHODS}

Materials. The crystalline alcohol oxidase preparation was prepared from the cell-free extract of Kloeckera sp. No. 2201 grown on the methanol medium, as previously described." Purified beef liver catalase and purified horseradish peroxidase were purchased from Sigma Chemical Co., U.S.A. Leaf alcohol was a kind gift of Dr. O. Adachi, Yamaguchi University. Other chemicals were obtained from commercial sources and used without further purification.

Activity measurement. To estimate the oxidase activity for methanol, the following standard assay conditions were used: The assay mixture which contained $16 \mu$ moles of methanol, $300 \mu$ moles of potassium phosphate buffer, $\mathrm{pH} 7.5$, and an appropriate amount of crystalline enzyme in a total volume of $2.8 \mathrm{ml}$. Incubation was carried out for $30 \mathrm{~min}$ at $37^{\circ} \mathrm{C}$ and stopped by the addition of $0.2 \mathrm{ml}$ of $4 \mathrm{~N}$ $\mathrm{HCl}$. Any precipitate formed was removed by centrifugation and the supernatant fluid was used for the determination of formaldehyde.

When substrates other than methanol were used, the enzyme activity was assayed by the determination of hydrogen peroxide formed as follows: The reaction mixture which contained $224 \mu \mathrm{g}$ of peroxidase, 1 t umoles of potassium phosphate buffer, $\mathrm{pH} 7.5$, and the enzyme in a total volume of $2.8 \mathrm{ml}$. Incubation was carried out at $30^{\circ} \mathrm{C}$ for $30 \mathrm{~min}$ and stopped by the addition of $0.2 \mathrm{ml}$ of $4 \mathrm{~N} \mathrm{HCl}$. The amount of resulted color complex was measured colorimetrically. The reading was corrected for blank, which 
was obtained from enzyme and reagents without methanol.

Analytical methods. Formaldehyde, hydrogen peroxide and protein were determined spectrophotometrically as previously described.11 Measurement of oxygen consumption was made in a Warburg apparatus.

Spectrophotometric determinations. The spectrophotometric determinations were carried out using a Hitachi Perkin-Elmer Spectrophotometer 139. The spectra of the enzyme were taken with a Shimadzu multipurpose autorecording spectrophotometer $50 \mathrm{~L}$.

Paper chromatography. Solvent mixtures used for the paper chromatography of flavin derivatives have the following composition"1 (volume per volume); $n$ butanol, 50; acetone, 20; acetic acid, 10; water, 30 (solvent A) and $n$-butanol, $40 ;$ methanol, $20 ; 0.5 ?_{0}$ disodium phosphate, 10 (solvent $B$ ). The ascending paper chromatography with Toyo Roshi No. 53 filter paper was carried out under the dark conditions.

\section{RESULTS}

Identification of prosthetic group of the enzyme Absorption spectra of the enzyme. The spectrum of the native enzyme is shown in Fig. 1. Over the wavelength investigated, the enzyme exhibited one absorption maximum in ultraviolet range at $280 \mathrm{~m} \mu$ and three maxima in visible range at $373 \mathrm{~m} \mu, 392 \mathrm{~m} \mu$ and $461 \mathrm{~m} \mu$. Two absorption maxima $(373 \mathrm{~m} \mu$ and $461 \mathrm{~m} \psi$ ) may suggest the contribution of a flavin derivative to the enzyme as prosthetic group. The absorption at $392 \mathrm{~m} \mu$ may suggest the presence of the other chromophore(s), but it has not been investigated yet. The addition of methanol to the enzyme under anaerobic conditions resulted in a decrease of the visible absorption spectrum (Fig. 2). However, the bleaching of the absorption peaks was not complete under the conditions. The visible absorption spectrum was subsequently restored by bubbling oxygen into the solution. The absorption band was also partially bleached by the addition of excess sodium dithionite.

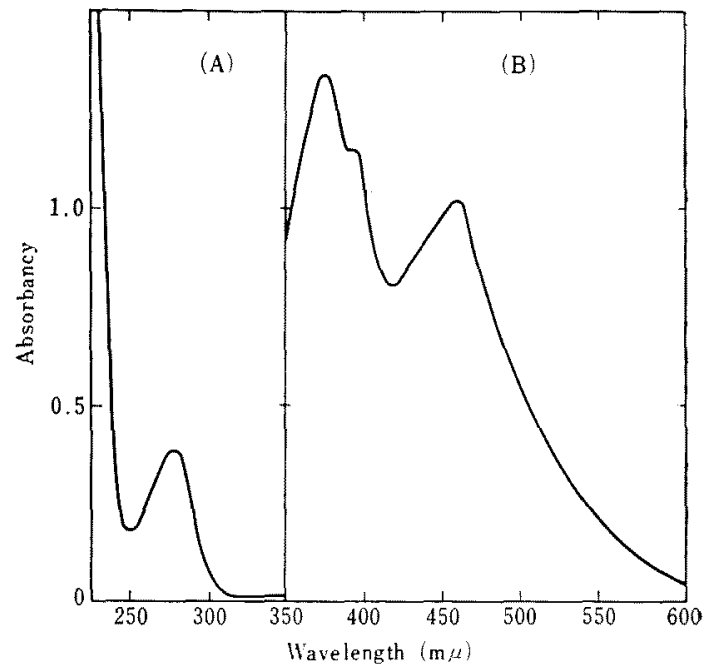

FIG 1. Absorption Spectrum of the Enzyme.

Crystallized enzyme was used at a concentration of $0.03 \%$ (A) and $0.80^{\circ}$ (B) in $0.01 \mathrm{M}$ potassium phosphate buffer, pH 7.5.

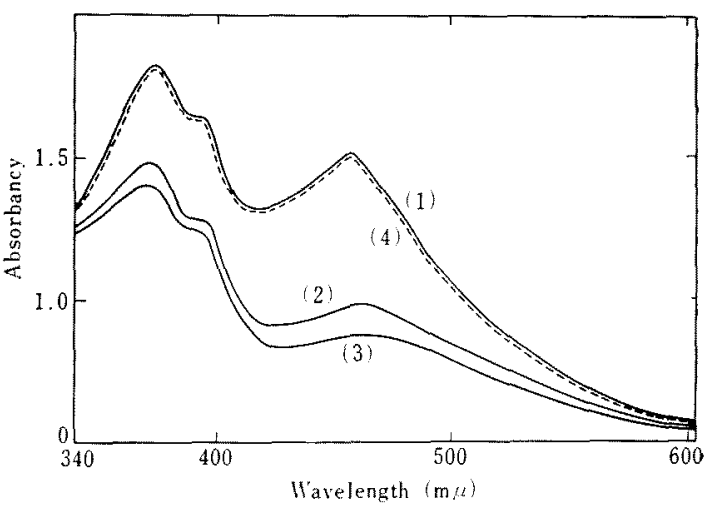

FIG. 2. Reaction of Enzyme with Substrate.

Crystallized enzyme was used at a concentration of 0.80 in $0.01 \mathrm{M}$ potassium phosphate buffer, $\mathrm{pH}$ 7.5. Absorption spectra: (1) before addition of methanol, (2) $2 \mathrm{~min}$ and (3) $20 \mathrm{~min}$ after addition of 1 umole of methanol, (4) after subsequent oxygenation.

Identification of the flavin derivative in the enzyme. A resolution of the purified enzyme by trichloroacetic acid was performed by the 
methed described by Swoboda and Massey. ${ }^{31}$ The enzyme solution containing $5 \mathrm{mg}$ of protein was first subjected to a short heat treatment $\left(5 \mathrm{~min}, 100^{\circ} \mathrm{C}\right)$ and then trichloroacetic acid was added to the solution to a final concentration of $5 \%$. A clear yellow supernatant obtained from the mixture by centrifugation was washed with ether. Figure 3 shows the absorption spectrum of the extract of the enzyme. The visible spectrum of the extract coincides with that of flavin derivatives.

Subsequently, an aliquot of the extract of the enzyme was employed for identification of the flavin by paper chromatography. The result is shown in Table I. The flavin extracted from the enzyme migrated at the

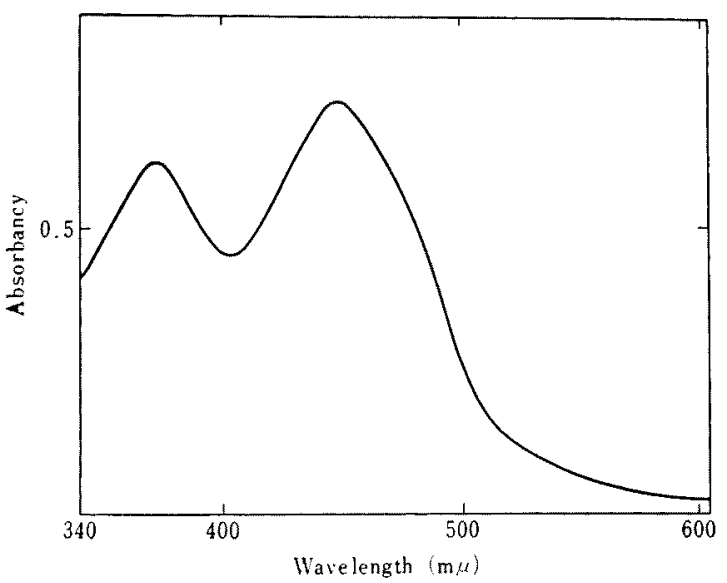

FIG. 3. Absorption Spectrum of Extract of the Enzyme.

The extraction was carried out as described in the text.

Table I. Paper Chromatography of Flavin FROM THE ENZYME

\begin{tabular}{lcc}
\hline Flavin derivative & $\begin{array}{c}\text { Migration } \\
\text { in solvent A }\end{array}$ & $\begin{array}{c}\text { Migration } \\
\text { in solvent B }\end{array}$ \\
\hline Extract of the enzyme & $2.4 \mathrm{~cm}$ & $2.8 \mathrm{~cm}$ \\
FAD & 2.4 & 3.4 \\
FMN & 7.3 & 8.7 \\
Riboflavin & 12.9 & 9.5 \\
\hline
\end{tabular}

same distance as FAD in both paper chromatographic systems.

From these results, the methanol-oxidizing enzyme was characterized to be a flavoprotein containing FAD as prosthetic group. On the assumption that the enzyme-bound FAD had the same extinction coefficient as free FAD, ${ }^{4}$ the FAD content was tentatively calculated to be 6 moles per mole $(570,000 \mathrm{~g})$ of the enzyme.

\section{Properties of the enzyme}

Effects of temperature and $p H$ on the enzyme stability. The enzyme in $0.04 \mathrm{M}$ buffer solution of various $\mathrm{pH}$ values was heated for $10 \mathrm{~min}$ at various temperatures, and then the remaining activity was assayed. As shown in Fig. 4, the enzyme was very unstable in the acidic $\mathrm{pH}$ and higher tempera-

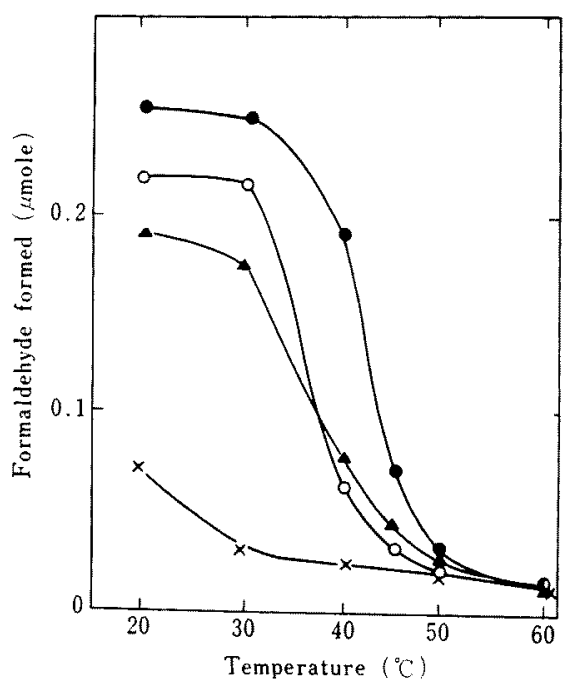

FIG. 4. Effects of Temperature and $\mathrm{pH}$ on the Enzyme Stability.

The enzyme solution containing $1 \mu \mathrm{g}$ of protein in $0.04 \mathrm{M}$ acetate buffer, $\mathrm{pH} 5.0(x), \mathrm{pH} 5.5(\boldsymbol{\Delta})$, $0.04 \mathrm{M}$ potassium phosphate buffer, $\mathrm{pH} 7.5(\mathbf{0})$, and $0.04 \mathrm{M}$ boric acid- $\mathrm{NaOH}$ buffer, $\mathrm{pH} 10.0(0)$, respectively, was heated for $10 \mathrm{~min}$ at various temperatures as indicated.

The remaining activity was measured under the standard assay conditions. 
tures. The activity was almost lost above $70^{\circ} \mathrm{C}$ under the conditions used.

Effect of temperature on the enzyme activity. The activity of enzyme was measured at various temperatures (Fig. 5). The optimum temperature was found to be near at $35^{\circ} \mathrm{C}$.

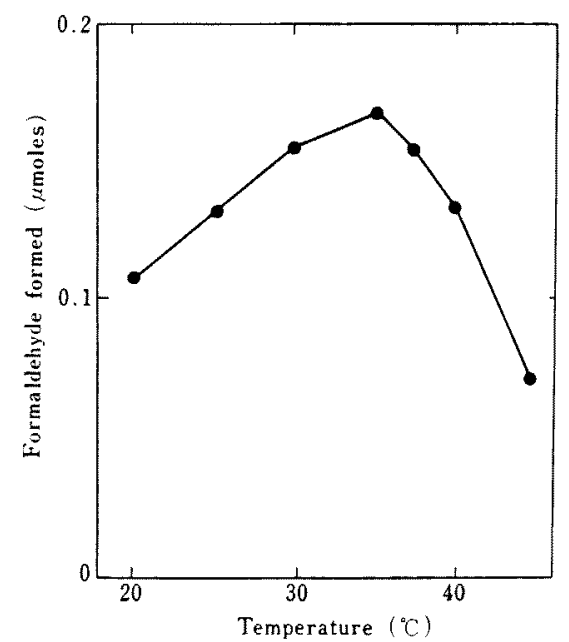

FIG. 5. Effect of Temperature on Enzyme Activity.

The enzyme activity was measured under the standard assay conditions with crystallized enzyme $(0.5 \mu \mathrm{g})$.

Effect of $p H$ on the enzyme activity. The enzyme activity was measured at various $\mathrm{pH}$ ranges (Fig. 6). The optimum $\mathrm{pH}$ was found to be at 8.0 in boric acid- $\mathrm{NaOH}$ buffer. The activity of enzyme in boric acid- $\mathrm{NaOH}$ buffer was lower than that in potassium phosphate buffer. It seemed that boric acid- $\mathrm{NaOH}$ buffer somewhat hindered the determination of formaldehyde. Tris-HCl buffer could not be used for its disturbance on formaldehyde determination.

Incubation time and enzyme concentration. The enzyme activity as functions of incubation time and enzyme concentration was investigated. The enzyme activity showed a linear relation with the incubation time until 30

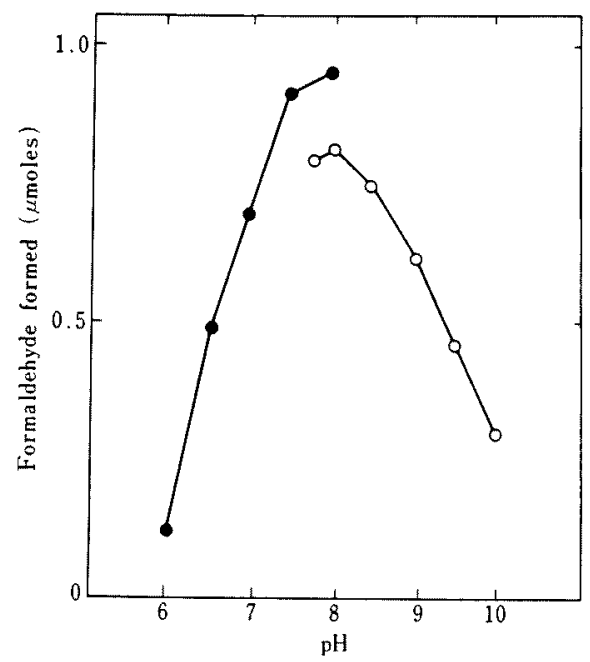

FIG. 6. Effect of $\mathrm{pH}$ on the Oxidation of Methanol.

Crystallized enzyme ( $3 \mu \mathrm{g}$ ) was used and the enzyme activity was measured under the standard assay conditions except for potassium phosphate buffer (-) or boric acid- $\mathrm{NaOH}$ (O) of various pHs.

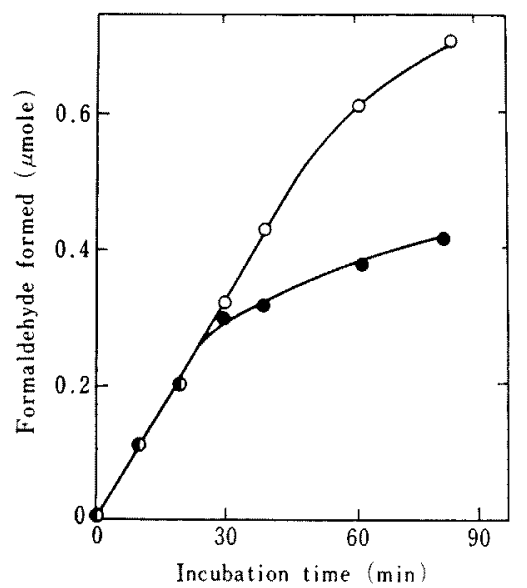

FIG. 7. Effect of Incubation Time on the Oxidation of Methanol.

Crystallized enzyme $(3 \mu \mathrm{g})$ was used and the enzyme activity was measured under the standard assay conditions except for incubation time and temperature at $28^{\circ} \mathrm{C}$. The plots (O) give the enzyme activity on the reciprocal shaking reaction (280 $\mathrm{rpm} / \mathrm{min}$ ) and plots (a) give that on the static reaction. 


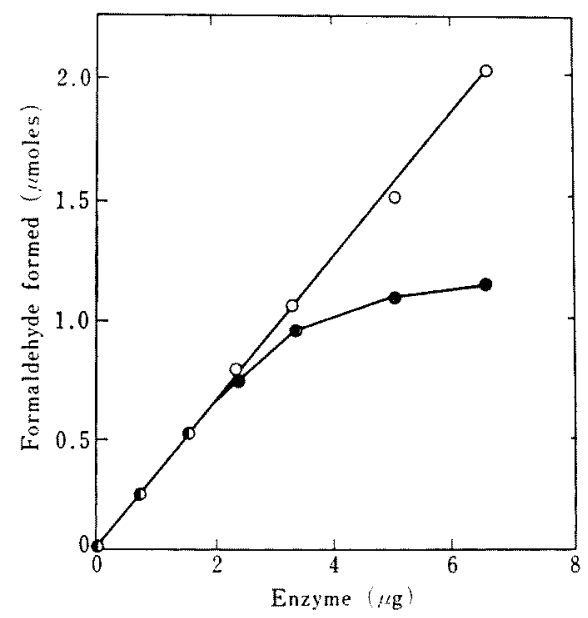

FIG. 8. Effect of Enzyme Concentration on the Oxidation of Methanol.

The enzyme activity was measured under the standard assay conditions with $(O)$ or without addition of catalase ( 25 units $/ \mathrm{ml}$ ).

min (Fig. 7). Over $30 \mathrm{~min}$, the curve of the enzyme activity inclined when the reaction was carried out without aeration. Under aeration, a linear relationship continued until $90 \mathrm{~min}$. The effect of the concentration of the enzyme on the reaction velocity was investigated under both the conditions with and without catalase. As shown in Fig. 8, a linear relationship was obtained till $3 \mathrm{\mu g}$ of the enzyme in both cases. However, without catalase, the formation of formaldehyde was suppressed in higher enzyme concentrations. A linear relationship continued under the conditions with catalase. This result suggests that hydrogen peroxide formed inhibits the reaction or that formaldehyde formed is oxidized by hydrogen peroxide.

Effect of substrate concentration on the reaction rate. The oxidase activities with various concentrations of methanol and ethanol were investigated. A plot of the reciprocal of the reaction velocity against the reciprocal of the substrate concentration is shown in Fig. 9. The Michaelis constants $(\mathrm{Km})$ for methanol

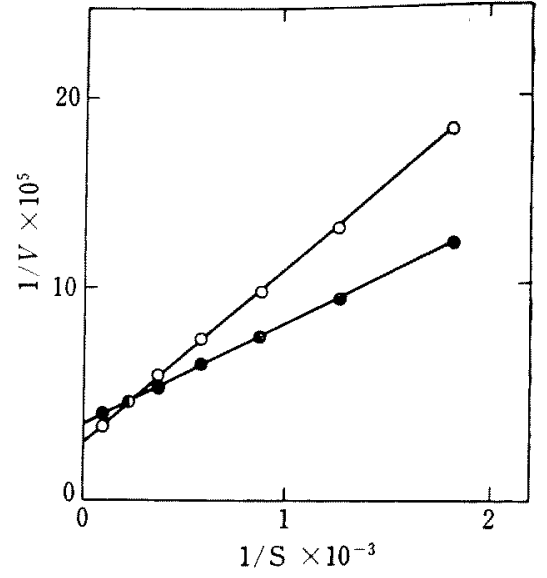

FIG. 9. Effect of Methanol or Ethanol Concentration on the Reaction Rate.

Crystallized enzyme $(0.5 \mu \mathrm{g})$ was used and the enzyme activity was measured under the standard assay conditions except for substrate concentration. Velocity $(V)$ was expressed as moles of hydrogen peroxide formed per min.

(-); methanol, (O); ethanol.

and ethanol were calculated to be $1.25 \times 10^{-3} \mathrm{M}$ and $2.5 \times 10^{-3} \mathrm{M}$, respectively, according to the method of Lineweaver and Burk. ${ }^{5 !}$

Effect of metal ion on the enzyme activity. The effect of various metal ions on the oxidation of methanol by the enzyme is shown in Table II. None of the metal ion tested stimulated the enzyme activity, but most of them gave the inhibitory effect. The enzyme activity was remarkably inhibited by cadmium and cupric ions at a concentration of $1 \times 10^{-3} \mathrm{M}$.

Effect of inhibitor on the enz yme activity. The effect of various reagents on the oxidation of methanol by the enzyme was studied. The enzyme activity was completely inhibited by such sulfhydryl reagents as $p$-chloromercuribenzoic acid and mercuric chloride at a concentration of $1 \times 10^{-3} \mathrm{M}$. Mercuric chloride showed the inhibitory effect even at the lower concentration $\left(1 \times 10^{-6} \mathrm{M}\right)$. The activity was slightly inhibited by 0 -phenanthroline and 8- 
TABlE II. EFFECT OF METAL ION ON ENzyME ACTIVITY

Crystallized enzyme $(1.2 \mu \mathrm{g})$ was used and the enzyme activity was measured under the standard assay conditions with addition of metal ion in a final concentration of $10^{-3} \mathrm{M}$. The reaction was initiated by addition of substrate after the enzyme was preincubated with metal ion for $10 \mathrm{~min}$.

\begin{tabular}{lc}
\hline Metal ion & Formaldehyde formed \\
\hline & (Relative activity) \\
$\mathrm{Fe}^{2+}$ & 67 \\
$\mathrm{Fe}^{3+}$ & 64 \\
$\mathrm{Zn}^{2+}$ & 54 \\
$\mathrm{Mn}^{2+}$ & 77 \\
$\mathrm{Mg}^{2-}$ & 84 \\
$\mathrm{Ni}^{2-}$ & 34 \\
$\mathrm{Ca}^{2+}$ & 78 \\
$\mathrm{Co}^{2+}$ & 69 \\
$\mathrm{Cd}^{2+}$ & 10 \\
$\mathrm{Cu}^{2-}$ & 1 \\
$\mathrm{Li}^{-}$ & 78 \\
$\mathrm{Al}^{3-}$ & 82 \\
$\mathrm{Hg}^{2+}$ & 0 \\
$\mathrm{None}^{2+}$ & $(100)$ \\
\hline
\end{tabular}

hydroxyquinoline. Ethylenediaminotetraacetic acid was not inhibitory even at the higher concentration $\left(1 \div 10^{-2} \mathrm{M}\right)$.

Substrate specificity of alcohol oxidase. The oxidation rates of various alcohols by the oxidase are shown in Table III. It shows that methanol, ethanol, n-propanol, $n$-butanol, allyl alcohol, chloroethanol and bromoethanol are effective as substrate. Leaf alcohol, $\beta \gamma$-cishexen-1-ol, which was found in the most foliage $^{6 /}$ and known to be oxidized by allyl alcohol dehydrogenase of Escherichia coli, ${ }^{1 "}$ was somewhat oxdized by the enzyme. These results indicate that the oxidase is an alcohol oxidase which shows a broad substrate specificity for short chain normal primary aliphatic alcohols and that ethanol is the best substrate besides methanol.
Table III. Substrate Specificity of the ENZYME

Crystallized enzyme $(2 \mu \mathrm{g})$ was used and the enzyme activity was measured as described in Materials and Methods. The oxidation of leaf alcohol was manometrically measured.

\begin{tabular}{lc}
\multicolumn{1}{c}{ Substrate } & Relative activity \\
\hline Methanol & 100 \\
Ethanol & 106 \\
$n$-Propanol & 48 \\
$n$-Butanol & 31 \\
$n$-Hexanol & 1 \\
$n$-Octanol & 1 \\
2-Chloroethanol & 28 \\
2-Bromoethanol & 20 \\
2-Aminoethanol & 0 \\
2-Phenylethanol & 1 \\
Ethylene glycol & 3 \\
Propylene glycol & 0 \\
Allyl alcohol & 67 \\
Glycerol & 0 \\
Isopropanol & 3 \\
Isobutanol & 2 \\
tert-Butanol & 0 \\
Isoamyl alcohol & 1 \\
tert-Amyl alcohol & 0 \\
Benzyl alcohol & 0 \\
Leaf alcohol & 10 \\
\hline
\end{tabular}

\section{DISCUSSION}

The visible absorption spectrum of alcohol oxidase of Kloeckera sp. No. 2201 was somewhat unlike to that of FAD which bound to the enzyme as prosthetic group and had apsorption maxima at $375 \mathrm{~m} \mu$ and $450 \mathrm{~m} \mu$. It may be possible that the spectrum of the flavin is modified by binding to the enzyme protein. In that the absorption maximum at $373 \mathrm{~m} \mu$ was higher than that at $462 \mathrm{~m} / \mu$, the enzyme differed from other usual flavin enzymes. The absorption at $392 \mathrm{~m} \mu$ suggests that the other chromophores may contribute to the enzyme spectrum, like that of xanthine oxidase which is a FAD-enzyme with heavy molecular weight and contains molybdenum or iron. ${ }^{8,97}$ The addition of substrate to the enzyme under anaerobic conditions produced 
a decrease of the visible absorption spectrum but a complete bleaching of two absorption peaks at $373 \mathrm{~m} \mu$ and $461 \mathrm{~m} \mu$ which was reported in L-amino acid oxidase, ${ }^{10}$ did not occur in this enzyme. The decrease of visible absorption spectrum was restored by bubbling oxygen.

The similarity of the reaction rate with or without catalase in the early stage of the reaction indicates that hydrogen peroxide produced does not react nonenzymatically with a small amount of formaldehyde. Therefore, the addition of catalase in the reaction mixture was not necessary in routine enzyme assays. The alcohol oxidase from Kloeckera sp. No. 2201 has a $\mathrm{pH}$ optimum at 8.0 , whereas it has been reported that the alcohol oxidase from basidiomycete had a broad $\mathrm{pH}$ optimum from 6.5 to $9.0 .^{11}$ Unstability in a acidic environment was the same in two oxidases. The enzyme activity was completely inhibited by sulfhydryl reagents. This finding suggests that -SH group of the enzyme plays a significant role in the enzyme reaction as reported in succinate dehydrogenase, which has FAD and nonheme iron bound to $-\mathrm{SH}$ groups. ${ }^{12 !}$

Alcohol dehydrogenases linked NAD from yeast and horse liver readily oxidize primary alcohols except for methanol. ${ }^{13)}$ NADP-alcohol dehydrogenase shows a similar behavior but scarcely oxidizes methanol. ${ }^{14}$ A significant oxidation of methanol by alcohol dehydrogenases has been reported with enzymes from human liver ${ }^{15}$ and methanol-grown bacteria. ${ }^{161}$ The latter enzyme showed a broad substrate specificity on primary alcohols. An alcohol oxidase of basidiomycete also oxidizes methanol. ${ }^{11,17}$ Then, the enzyme has been proposed to be useful for the determination of the lower primary alcohols. ${ }^{181}$ It is indicated in this study that the alcohol oxidase of Kleockera sp. No. 2201 catalyzes the oxidation of the lower primary alcohols to the corresponding aldehyde. Ethanol was oxidized in $106 \%$ of reactivity in comparison with methanol by the enzyme, while it was reported that ethanol was oxidized in only $28 \%$ of reactivity in comparison with methanol by the enzyme from basidiomycete. ${ }^{11}$

On the microbial utilization of $\mathrm{C}_{1}$ compounds as a sole carbon source, their biochemical singularity lies in their ability to synthesize all their cell constituents and to produce the energy from $\mathrm{C}_{1}$ compounds. The presence of serine pathway ${ }^{151}$ and ribose phosphate cycle ${ }^{201}$ was suggested with a pseudomonad grown on methanol or methane. The pathway of the metabolism of methanol in Kloeckera sp. No. 2201 is now under study in our laboratory. The presence of NADformaldehyde dehydrogenase, which may be coupled with energy reproduction system, has been confirmed.*

Acknowledgement. The authors wish to thank Drs. H. Yamada and K. Soda, Kyoto University, for their advices in this work.

\section{REFERENCES}

1) Y. Tani, T. Miya, H. Nishikawa and K. Ogata, Agr. Biol. Chem., 36, 68 (1972).

2) J. H. Pazur, K. Kleppe and A. Cepure, Arch. Biochem. Biophys., 111, 35 (1965).

3) B. E. P. Swoboda and V. Massey, J. Biol. Chem., 240, 2209 (1965).

4) L. G. Whitby, Biochem. J., 54, 440 (1953).

5) H. Lineweaver and D. Burk, J. Am. Chem. Soc., 56, 658 (1934).

6) S. Takei, Y. Sakato, M. Ohno and Y. Kuroiwa, Nippon Nogeikagaku Kaishi, 14, 709 (1938).

7) A. Hatanaka, O. Adachi and M. Ameyama, Agr. Biol. Chem., 34, 1574 (1970).

8) D. B. Morell, Biochem. J., 51, 657 (1952).

9) B. Mackler, H. R. Mahler and D. E. Green, J. Biol. Chem., 210, 149 (1954).

10) D. Wellner and A. Meister, ibid., 235, PC 12 (1960).

11) F. W. Janssen and H. W. Ruelius, Biochim. Biophys. Acta, 151, 330 (1968).

12) V. Massey, J. Biol. Chem., 229, 763 (1957).

* Unpublished observation. 
13) H. Sund and H. Theorell, "The Enzymes," Vol. 17) W. H. Orme-Johnson and D. M. Ziegler, Bio6, ed. by P. D. Boyer, H. Lardy and K. Myrback, Academic Press, 1963, p. 25.

14) R. D. DeMoss, J. Bacteriol., 68, 252 (1954).

15) J. P. Wartburg, J. L. Bethune and B. L. Vallee, Biochemistry, 3, 1775 (1964).

chem. Biophys. Res. Commun., 21, 78 (1965).

18) G. G. Guilbault, "Enzymatic Methods of Analysis," Pergamon Press, 1970, p. 156.

19) T. Kaneda and J. M. Roxburgh, Can. J. Microbiol., 5, 187 (1959).

16) C. Anthony and L.J. Zatman, Biochem. J., 96, 20) M. B. Kemp and J. R. Quayle, Biochem.J., 102, 808 (1965). 94 (1967). 